DOI 10.315092658-607x-2018-1-1-1-17

УДК 581.93

ОБЗОР ФЛОРЫ ЛЕСОВ ЦЕНТРАЛЬНОГО ПРЕДКАВКАЗЬЯ

(C) 2018 г.

Н.Е. Шевченко

Центр по проблемам экологии и продуктивности лесов РАН

Россия, 117997 Москва, ул. Профсоюзная, 84/32, стр. 14

E-mail: neshevchenko@gmail.com

Поступила в редакцию 22.08.2018 г.

В статье рассмотрено таксономическое, эколого-ценотическое и географическое разнообразие флоры лесов Центрального Предкавказья, насчитывающей 735 видов сосудистых растений, относящихся к 101 семейству и 353 родам. Таксономическая структура флоры лесов по составу первых десяти семейств соответствует флоре Предкавказья. Леса имеют европейско-субсредиземноморско-евразийский с бореальной и кавказской примесью спектр географических элементов. Общий ход развития флоры лесов региона, как и лесов Восточноевропейской равнины, шел в направлении инкубации европейского комплекса на субсредиземноморские и бореальные типы с постепенным их вытеснением.

Ключевые слова: Центральное Предкавказье, леса, флора, таксономическая структура, эколого-иенотиечская группа, биморфа, геоэлемент

В настоящее время более $70 \%$ площади лесов Центрального Предкавказья сосредоточено на Ставропольской возвышенности и предгорьях Кавказских Минеральных Вод. Пограничное положение между флористическими комплексами Русской равнины и Северного Кавказа привело к обогащению лесной флоры лесов Центрального Предкавказья субсредиземноморскими, кавказскими и средиземноморскими видами. В лесах произрастает 58 редких и исчезающих видов растений, занесенных в Красную Книгу Ставропольского края (2002) и РФ (2008), такие виды как Anemone caucasica, Asarum caucasicum, Erythronium caucasicum, Galanthus alpinus, Hedera helix, Ornithogalum arcuatum и др. Леса Центрального Предкавказья сформированы дубово-грабово-ясеневыми и буково-дубово-грабовыми сообществами. Буковые сообщества сохранились лишь на плакорах Ставропольских высот, склонах Кавказских Минеральных Вод и Терско-Сунженского хребта. По балкам степных рек Прикалаусских высот встречаются байрачные леса с преобладанием дубово-грабовоясеневых и дубово-ясеневых сообществ. В поймах рек распространены дубово-тополевые и дубово-вязово-ясеневые сообщества (Шевченко, 2013; Шевченко, Викторов, 2014). Леса Центрального Предкавказья сохранились в виде небольших фрагментов единого лесного пояса, простиравшегося в начале позднего голоцена по линии Приэльбрусье Ставропольская возвышенность - Ергени (Гричук, 1952; Федорова, 1955; Матишов, Калмыков, 2013). 
Цель работы - таксономический, эколого-ценотический и географический анализ флоры лесов Центрального Предкавказья.

\section{МАТЕРИАЛ И МЕТОДЫ}

Материал собран автором в ходе экспедиционных исследований на территории Центрального Предкавказья в 2005-2012 гг. Изучение лесов проводилось маршрутнорекогносцировочным методом в сочетании с детальным обследованием флоры и растительности отдельных участков. Всего было собрано около 3000 гербарных образцов. В настоящее время собранный материал хранится в гербарии Московского педагогического государственного университета (MOSP).

Изучен гербарный материал, хранящийся в фондах БИН РАН (LE), ГБС РАН (MHA), МГУ им. М.В. Ломоносова (MW), МПГУ (MOSP), Ставропольского государственного университета (SPI), Ставропольского государственного музея-заповедника им. Г.Н. Прозрителева и Г.К. Праве (SMRS), Ставропольского ботанического сада (SBG), СевероОсетинского государственного университета (СОГУ), Эколого-ботанической станции БИН РАН (г. Пятигорск).

Номенклатура видов приводится по сводкам С.К. Черепанова (1995), А.С. Зернова, В.Г. Онипченко (2011).

\section{РЕЗУЛЬТАТЫ И ОБСУЖДЕНИЕ}

Под таксономической структурой мы понимает соотношение таксонов разного ранга. На основе материалов наших исследований конспект флоры лесов Центрального Предкавказья насчитывает 773 вида сосудистых растений, из них 735 видов подтверждены личными сборами автора и гербарным материалом других исследователей (Шевченко, Белоус, 2013). Все виды относятся к 101 семейству и 353 родам, из них 9 видов представлены не натурализовавшимся адвентиками.

Наличие во флоре лесов Центрального Предкавказья 29 видов сосудистых растений, приведенных в литературных источниках, не подтверждено полевыми и камеральными исследованиями. Это такие виды: Adiantum capillus-veneris L., Equisetum sylvaticum L., Dactylis lobata (Drej.) Lindb. f., D. polygama Horvat., Poa iberica Fisch. et Mey., Carex depauperata Curt. ex With., Carex leporina L., Arum nordmannii Schott, Gagea chanae Grossh., Puschkinia scilloides Adams, Tulipa biebersteiniana Schult. et Schult. fil., Polygonum bellardii All., Paeonia caucasica (Schipcz.) Schipsz., Ranunculus. georgicus Kem.-Nath., Corydalis angustifolia (Bieb.) DC., Hesperis pycnotricha Borb. et Degen, H. sibirica L., Cotoneaster racemiflorus (Desf.) Booth ex Bosse, Crataegus meyeri A. Pojark., Viola selkirkii Pursh ex Goldie, Chaerophyllum prescottii DC., Melampyrum caucasicum Bunge, Orobancheво флоре лесов Центрального Предкавказья hederae Duby, Campanula alliariifolia Willd., Anthemis tinctoria 
L., Hieracium acuminatifolium (Litv. et Zahn) Juxip, H. stauropolitanum Juxip, H. beschtavicum (Litv. et Zahn) Juxip, H. medianiforme (Litv. et Zahn) Juxip. Для 412 видов на основе полевых материалов и гербария других авторов был утонен ареал во флоре лесов исследуемого региона (Шевченко, 2011; Шевченко, 2013; Шевченко, Белоус, 2014).

Об уровне таксономического разнообразия флоры лесов Центрального Предкавказья можно судить лишь в сравнении с данными видового разнообразия флор сопредельных территорий (рис. 1). Поскольку данных о видовом разнообразии флор лесов этих территорий нет, для сравнения, в работе нам приходится использовать лишь сведения о видовом разнообразии всей флоры этих регионов.

По уровню видового богатства и уровню флористического сходства леса Центрального Предкавказья близки к флоре лесов Восточноевропейской части России. В предгорных лесах Центрального Предкавказья в составе флоры лесных сообществ выше доля кавказских видов, что позволяет нам рассматривать флору лесов Центрального Предкавказья как переходную между флорами лесов Восточноевропейской части России и Кавказа.

Основу лесной флоры региона составляют представители отдела Magnoliophyta, насчитывающие 703 вида сосудистых растений (95.6\%, от общего числа видов) (табл. 1). К классу Magnoliopsida принадлежит 531 вид, а Liliopsida - 172 вида (72.2\% и 23.4\%, соответственно). Соотношение числа видов классов Magnoliopsida и Liliopsida - 3:1.

Изучение таксономической структуры включает также и определение численных соотношений между видовым и родовым составом флор (среднее число видов на один род), между численностью родов и семейств или непосредственно видов и семейств, входящих в состав данной флоры, так как эти показатели носят относительно устойчивый характер. Для флоры лесов Центрального Предкавказья среднее число видов на одно семейство составляет 7.27:1, а среднее число родов в семействах составляет 3.49:1.

Важнейшим показателем каждой флоры является соотношение ведущих семейств, то есть соотношение между числом видов различных семейств (Морозова, 2008). При сравнительном анализе флоры чаще всего используют не весь список, а лишь первые 10-15 ведущих семейств. Первые одиннадцать мест (табл. 1) по числу видов в составе изучаемой флоры занимают следующие семейства: Poaceae, Asteraceae, Rosaceae, Apiaceae, Fabaceae, Brassicaceae, Scrophulariaceae, Cyperaceae, Lamiaceae, Caryophyllaceae, Ranunculaceae. B процентном выражении суммарная доля видов, приходящихся на эти семейства, составляет $53 \%$ (390 видов).

В исследуемой флоре насчитывается 359 родов высших растений, из них к классу Magnoliopsida относятся 264 рода, а к классу Liliopsida - 77 родов (73.5\% и 21.4\% от общего числа родов, соответственно). На один род приходится в среднем 2.05 видов высших 
сосудистых растений. Для всей флоры Предкавказья этот показатель равен 3.16 (Иванов, 1998).
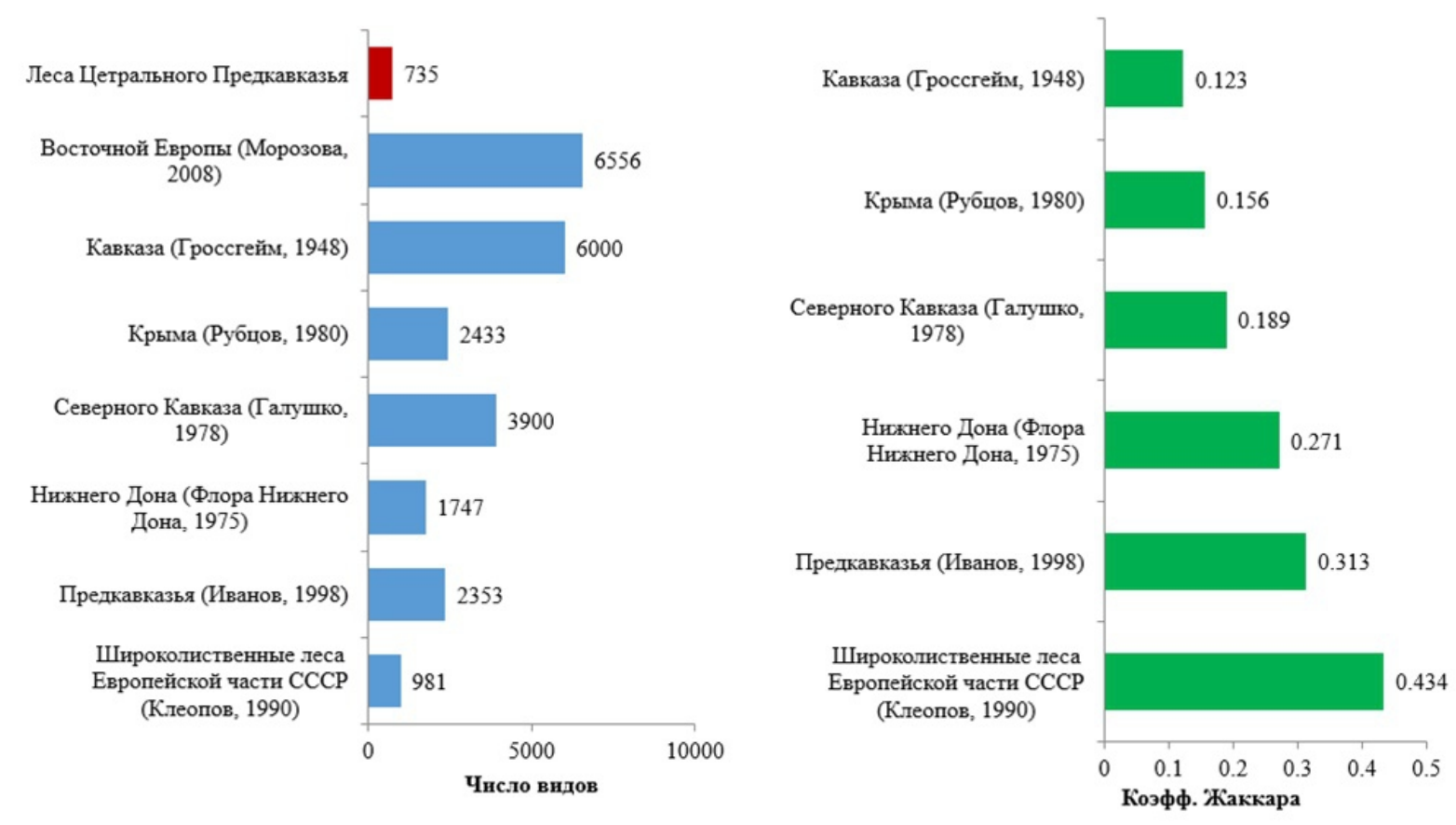

Рисунок 1. Соотношение флоры лесов Центрального с флорами сопредельных территорий

Родовая насыщенность семейства покрытосеменных растений флоры исследуемых лесов составляет 3.9:1. Наиболее крупными семействами (табл. 2) по числу родов являются Asteraceae, Poaceae, Apiaceae, Brassicaceae, Rosaceae, Lamiaceae.

Первые десять мест по числу видов во флоре лесов занимают рода Carex (17 видов, или $2.31 \%$ от общего числа видов), Viola (13/1.77), Veronica (11/1.5), Vicia (9/1.22), Geranium (8/1.1), Trifolium (8/1.1), Potentilla (7/0.9), Allium (6/0.8), Festuca (6/0.8) и Juncus (6/0.8). На первые 20 наиболее крупных родов приходится около $20 \%$ от общего числа видов.

Крупнейших родов, насчитывающих 20 и более видов (Иванов, 1998), в составе флоры лесов Центрального Предкавказья нет. Самым малочисленным являются крупные роды, насчитывающие от 10 до 19 видов. Они представлены 41 видом (5.5\% от общего числа видов), объединенных в 3 рода (0.9\% от общего числа родов флоры): Carex (17 видов), Viola (13) и Veronica (11).

Средних родов (от 9 до 5 видов) во флоре лесов региона 28 (7.9\%). По числу видов они подразделяются следующим образом: 9 видов - 1 род, 8 - 2 рода, 7 - 1 род, $6-11$ родов, 5 - 13 родов. Всего на долю этих родов приходится 163 вида (22.1\%). 
Таблица 1. Основные пропорции лесной флоры Центрального Предкавказья

\begin{tabular}{|l|c|c|c|c|c|c|c|c|}
\hline \multicolumn{1}{|c|}{ Отдел } & $\begin{array}{l}\text { число } \\
\text { видов }\end{array}$ & $\%$ & $\begin{array}{c}\text { число } \\
\text { родов }\end{array}$ & $\%$ & $\begin{array}{c}\text { число } \\
\text { семейств }\end{array}$ & $\%$ & пропорции & $\begin{array}{c}\text { род. } \\
\text { коэфф. }\end{array}$ \\
\hline Lycopodiophyta & 1 & 0.13 & 1 & 0.28 & 1 & 0.99 & $1: 1: 1$ & 1 \\
\hline Equisetophyta & 5 & 0.68 & 1 & 0.28 & 1 & 0.99 & $5: 1: 1$ & 5 \\
\hline Polypodiophyta & 22 & 2.99 & 14 & 3.97 & 8 & 7.92 & $3: 2: 1$ & 1.6 \\
\hline Pinophyta & 4 & 0.55 & 2 & 0.57 & 2 & 1.98 & $2: 1: 1$ & 2 \\
\hline Magnoliophyta & 703 & 95.65 & 335 & 94.90 & 89 & 88.12 & $8: 4: 1$ & 2.1 \\
\hline Bceго: & $\mathbf{7 3 5}$ & $\mathbf{1 0 0 . 0}$ & $\mathbf{3 5 3}$ & $\mathbf{1 0 0 . 0}$ & $\mathbf{1 0 1}$ & $\mathbf{1 0 0 . 0}$ & $\mathbf{7 : 3 . 6 : 1}$ & $\mathbf{2 . 1}$ \\
\hline
\end{tabular}

По числу видов во флоре лесов региона преобладают бедные рода (от 4 до 2 видов), они насчитывают 129 родов (36.5\%) и представлены 338 видами (45.9\%).

Роды с одним видом преобладают по числу родов, их насчитывается 193 рода (54.6\%), но отстают по общему числу видов - 193 (26.8\%). Большинство родов олиготипны или монотипны, за исключением некоторых, лишь относительно богатых видами: Lilium, Melandrium, Helleborus, Spirea и др.

Таблица 2. Соотношение десяти ведущих семейств флоры лесов Центрального Предкавказья по числу видов и числу родов*

\begin{tabular}{|l|l|c|c|c|c|}
\hline $\begin{array}{l}\text { № } \\
\text { п/п }\end{array}$ & \multicolumn{1}{|c|}{ семейство } & $\begin{array}{c}\text { число } \\
\text { видов }\end{array}$ & $\begin{array}{c}\text { \% от общего } \\
\text { числа видов }\end{array}$ & число родов & $\begin{array}{c}\text { \% от общего } \\
\text { числа родов }\end{array}$ \\
\hline 1. & Poaceae & 72 & 18.5 & 39 & 11.0 \\
\hline 2. & Asteraceae & 67 & 17.2 & 40 & 11.3 \\
\hline 3. & Rosaceae & 45 & 11.5 & 18 & 5.1 \\
\hline 4. & Apiaceae & 42 & 10.8 & 29 & 8.2 \\
\hline 5. & Fabaceae & 37 & 9.5 & 15 & 4.2 \\
\hline 6. & Brassicaceae & 31 & 7.9 & 20 & 5.7 \\
\hline 7. & Scrophulariaceae & 27 & 6.9 & 8 & 2.3 \\
\hline 8. & Cyperaceae & 25 & 6.4 & 5 & 1.4 \\
\hline 9. & Lamiaceae & 23 & 5.9 & 15 & 4.2 \\
\hline \multirow{2}{*}{10.} & Caryophyllaceae & 21 & 5.4 & 9 & 2.5 \\
\cline { 2 - 6 } & Bceго: & $\mathbf{3 9 0}$ & $\mathbf{5 3 . 0}$ & $\mathbf{1 9 8}$ & $\mathbf{5 6 . 1}$ \\
\hline
\end{tabular}

Примечание: * - семейства расположены в порядке уменьшения числа видов в них.

В таксономическом отношении флора лесов Центрального Предкавказья характеризуется разнородностью состава. К числу этих черт относится большой процент участия крупных семейств и родов, насчитывающих один вид. По составу первых десяти семейств флора лесов Центрального Предкавказья соответствует всей флоре Предкавказья. При этом соотношение этих семейств существенно отличается: преобладающим семейством 
по числу видов является Poaceae. Значительно выше доля семейств Rosaceae, Apiaceae, Boraginaceae и Orchidaceae, что сближает флору лесов района с флорой лесов Восточноевропейской равнины. По соотношению уровня видового разнообразия (78.9\%) и флористического сходства флора лесов Центрального Предкавказья близка к флоре лесов Восточноевропейской части России (коэффициент Жаккара - 0.434). Исходя из вышесказанного, флору лесов Центрального Предкавказья можно рассматривать как переходную между флорой Восточно-Европейской равнины и Северного Кавказа.

Под эколого-ценотической структурой мы понимаем соотношение числа видов флоры, приуроченных к определенным сообществам.

Ценотический состав позволяет проследить связи развития флоры с развитием различных типов растительности и обуславливающей его совокупностью условий среды, а также выявить своеобразные пути развития растительного покрова территории (Толмачев, 1974; Бурда, 1991).

Анализ эколого-ценотической структуры флоры лесов Центрального Предкавказья позволил выделить пять групп видов (рис. 2): лесные, луговые, водно-болотные, степные и сорные (рудеральные).

Лесные виды явно преобладают (332 вида, или 45.7\%) в эколого-ценотической структуре флоры. Они встречаются в 74 семействах, из них семейств, насчитывающих более 10 лесных видов - 12 (167 видов); от 5 до 9 - 8 (52); от 2 до 4 - 33 (92) и по 1 виду - 21 (21).

Лугово-опушечные виды (178 видов, или 24.2\%) распространены, главным образом, на лесных опушках и в светлых лесах. Они встречаются в 42 семействах и 117 родах. Семейств, насчитывающих свыше 10 луговых видов - 7 (112); от 5 до 9 - 2 (14); от 2 до 4 14 (33) и по 1 виду - 19 (19). Среди луговых видов выделяют субальпийские, которых насчитывается 26 видов (14.6\%). Например, Lilium monadelphum, Dactylorhiza flavescens, Trifolium caucasicum, Bupleurum falcatum, Heracleum wilhelmsii, Rhododendron luteum, Cicerbita macrophylla и др.

Виды околоводных и водных местообитаний насчитывается 101 (13.8\%), встречающихся 30 семействам и 48 родам. Семейств, насчитывающих более 10 видов - 2 (27 видов); от 5 до 10 - 5 (29); от 2 до 4 - 14 (37) и по 1 - виду - 9 (9). Эта группа видов подразделяется на три подгруппы: гигрофильный, гидрофильный и гидатофильный

.Виды, принадлежащие к гигрофильной подгруппе (77 видов, или $76.3 \%$ от общего числа видов водных и околоводных местообитаний), произрастают в местообитаниях с повышенным увлажнением почвы: Mycelis muralis, Petasites albus, P. hybridus, Tussilago farfara, Salix alba и др. 


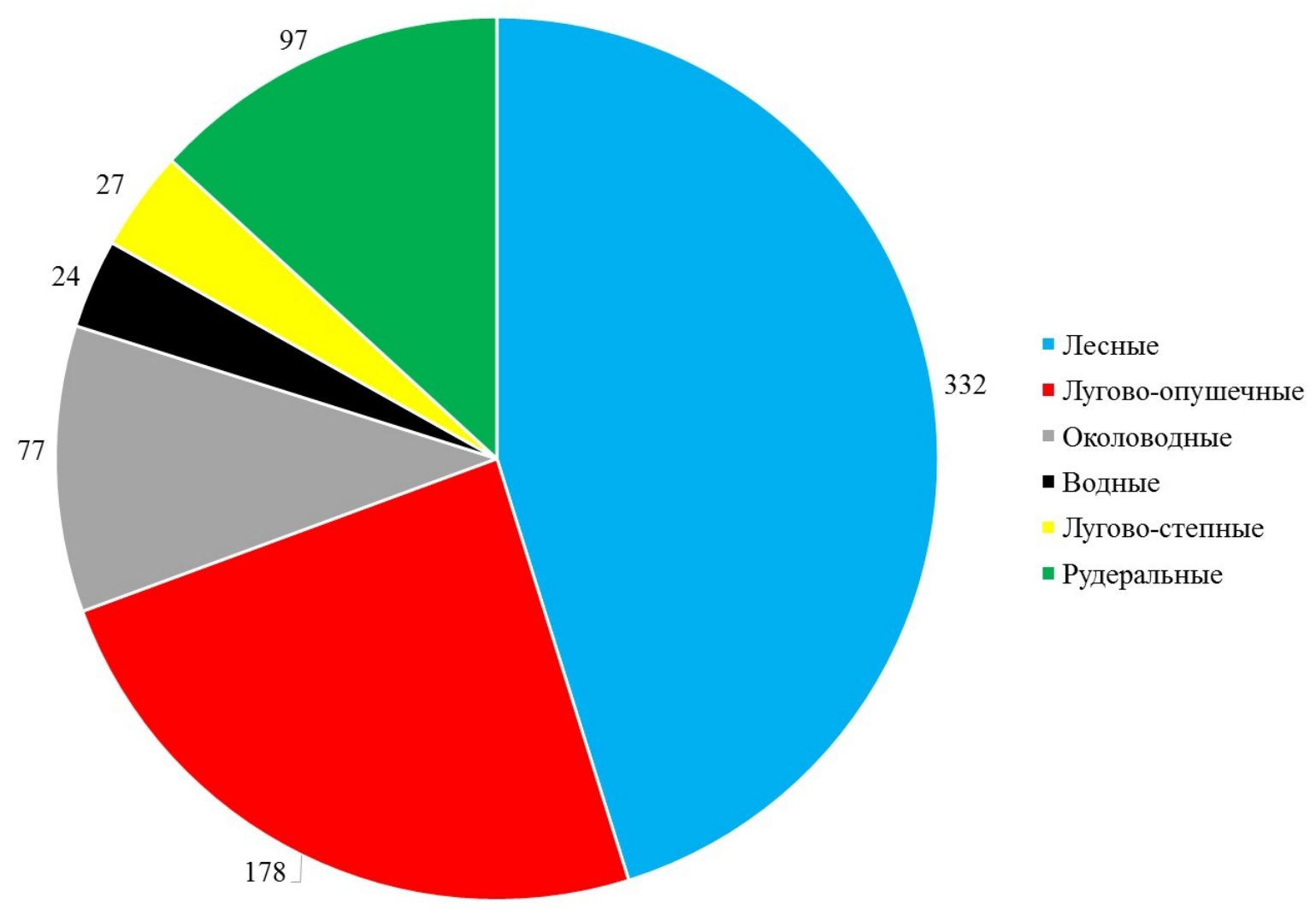

Рисунок 2. Соотношение эколого-ценотических групп флоры лесов Центрального Предкавказья

Относящиеся к гидрофильной подгруппе виды, представлены обитателями берегов водоемов и насчитывает 8 видов растений (7.8\%): Carex hordeistichos, Eleocharis acicularis, Polygonum amphybia, Ranunculus repens и др.

Принадлежащие к гидатофильной подгруппе виды (16 видов, или 15.7\%), произрастают в воде или плавают на еe поверхности: Lemna minor, Nuphaea alba, Potamogeton crispus и др.

Очень редко в единичных экземплярах на лесных опушках, светлых лесах и экотонных сообществах с высоким уровнем гетерогенности условий произрастания можно встретить лугово-степные виды (27 видов, или 3.6\%): Agropyron pectinatum, Eragrostis minor, Crocus speciosus, Cotinus coggygria и др.

Рудеральные (сорные) виды, как и степные чаще встречаются в сообществах с высоким уровнем гетерогенности условий произрастания - лесные дороги, опушки, канавы и т.д. Это Urtica dioica, Sclerochloa dura, Cannabis ruderalis, Chenopodium album, Ambrosia artemisifolia и др. 
Эколого-ценотическая структура флоры лесов Центрального Предкавказья отличается широким разнообразием. При этом лесные виды занимают не только господствующее положение по числу видов, но и ролью в структуре лесных сообществ. Остальные экологоценотические группы занимают преимущественно подчиненное положение. В целом эколого-ценотическая структура флоры региона соответствует структуре флоры широколиственных лесов Восточной Европы (Клеопов, 1990).

Биоморфа (жизненная форма), как известно, возникла исторически и отражает приспособленность растений той или иной группы к условиям среды. Разнообразный состав биоморф в растительном сообществе и связанная с этим сложность синузиального сложения последнего обеспечивают всестороннее использование живыми существами жизненных ресурсов местообитания, более и менее устойчивый максимум растительной продукции и наибольшую степень воздействия на среду, то есть ее биогенное преобразование. Биоморфологическая структура каждой флоры свидетельствует об адаптационных возможностях составляющих ее видов (Шевченко, Белоус, 2008).

В основу наших исследований положены две классификационные схемы жизненных форм: К. Раункиера (1905) и И.Г. Серебрякова (1962).

Биоморфологическая система К. Раункиера (рис. 3) рассматривает жизненную форму как комплекс адаптивных признаков и, в первую очередь, как способ защиты почек возобновления у растений в течение неблагоприятного сезона. Спектр жизненных форм, характерный для флоры лесов района исследования, представлен пятью группами биоморф, соотношение которых как по числу видов, так и по значению в структуре растительных сообществ неодинаково. Наибольшее число видов флоры - это травянистые растения (638 видов, или 86.8\%). Деревьев и кустарников и полукустарничков (фанерофиты + хамефиты) насчитывается 97 видов (13.2\%).

Анализ показывает достаточно высокий процент терофитов (16.6\%), что может быть объяснено большим участием в составе исследуемой флоре синантропных элементов. Однако большинство видов этой группы распространены в виде единичных особей лишь на территориях сильно нарушенных антропогенной деятельностью (вдоль дорог, троп, вблизи населенных пунктов и т. д.).

Доля хамефитов невелика (8.2\%). Ведущее положение в составе растительных сообществ занимают гемикриптофиты (32.5\%). Экологическая структура данной группы характеризуется присутствием не только лесных и луговых, но и гигрофильных и сорных групп. 


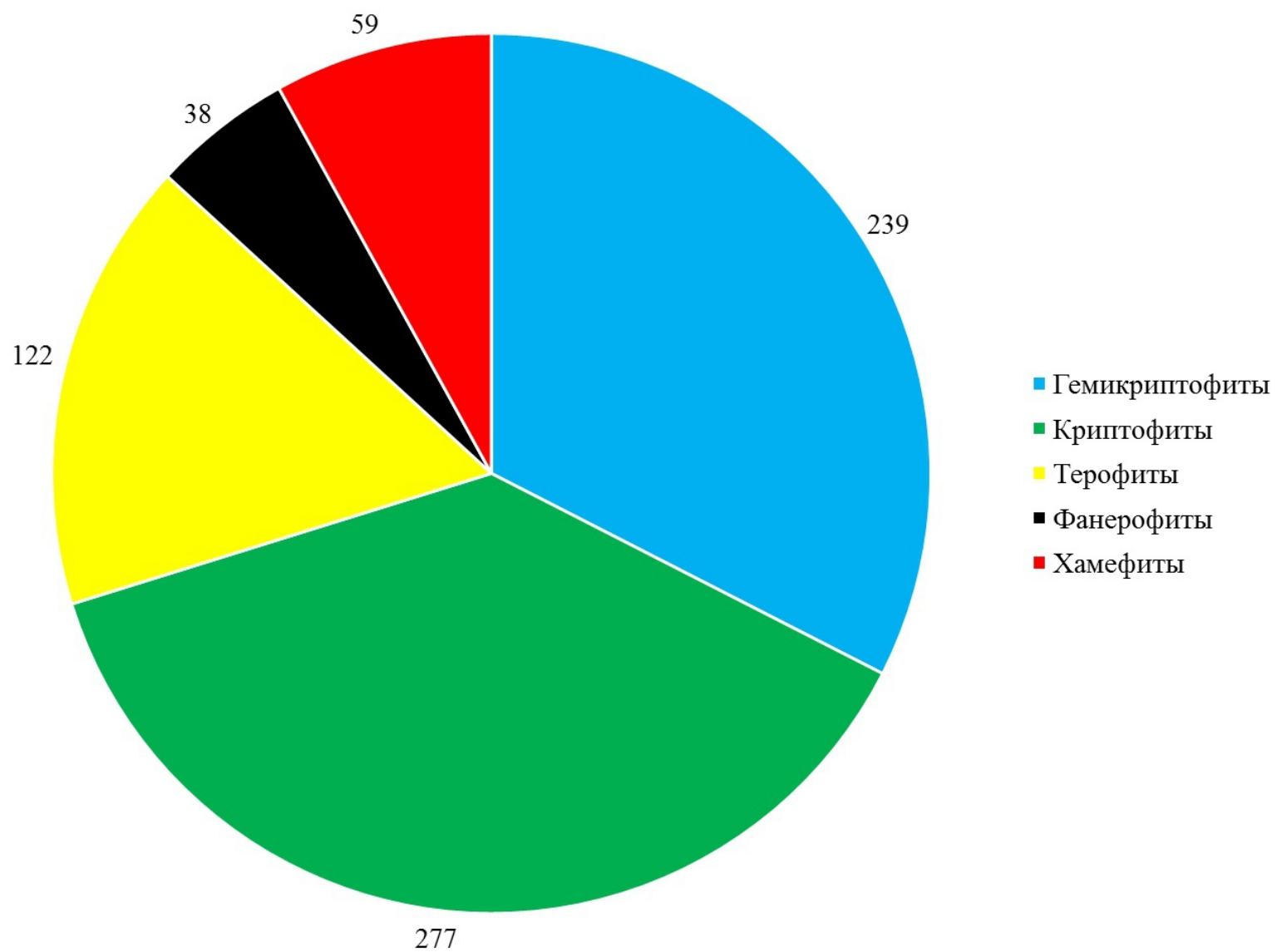

Рисунок 3. Соотношение биоморфологических групп флоры лесов Центрального Предкавказья (по К. Раункиеру, 1905)

Структура жизненных форм согласно классификации И.Г. Серебрякова отражает (рис. 4) преобладание травянистых поликарпиков (485 видов, или 65.9\%), среди которых наиболее многочисленны стержнекорневые (23.4\%), коротко- (22\%), длиннокорневищные (7.3\%), кистекорневые (5.8\%) и луковичные (2.8\%). Травянистые монокарпики насчитывают 156 видов (21.2\%) с преобладанием двулетних (4.8\%) и однолетних видов растений $(14.5 \%)$.

Древесных растениий 92 вида (12.5\%), при этом соотношение деревьев и кустарников одинаково. Полукустарнички представлены всего двумя видами.

Соотношение древесных и травянистых растений во флоре лесов Центрального Предкавказья полностью соответствует её зональному положению.

Под географической структурой мы понимаем распределение видов данной флоры по группам на основании сходства ареалов. Географический анализ флоры дает возможность установить связи между видами, входящими в ее состав, а также имеет большое значение для изучения процессов флорогенеза (Новосад, 1992; Шевченко Белоус, 2009). 


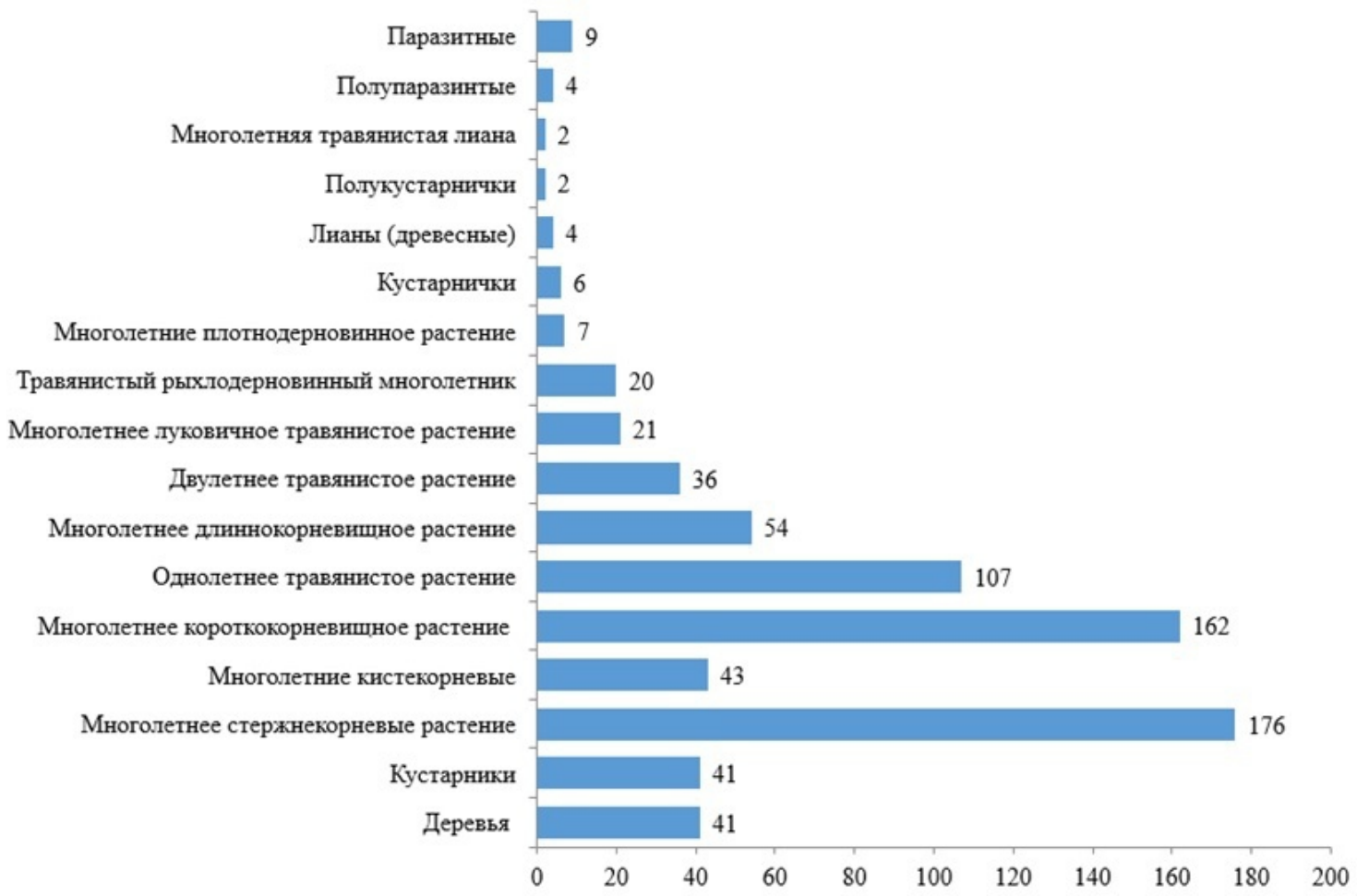

Рисунок 4. Соотношение биоморф флоры лесов Центрального

Предкавказья (по И.Г. Серебрякову, 1962)

Вопросы изучения ареалов и базовые принципы выделения географических элементов изложены в работах Е.В. Вульфа (1933), А.И. Толмачева (1974; 1986), Г. Вальтера (1975), Б.А. Юрцева (1987) и др. В зависимости от целей исследований используют различные классификационные схемы, выбор которых определяется характером самого флористического материала и задачами исследования.

Для территории Кавказа разработано большое разнообразие географических систем, построенных на основе разных концепций и взглядов (А.А. Гроссгейма $(1936 ; 1948)$, А.Л. Харадзе (1966), Р.И. Гагнидзе (1976), А.И. Галушко (1976), А.А. Сагателян (1997), Н.Н. Портениера (2000) и др.).

В основу системы геоэлементов флоры лесов Центрального Предкавказья была положена схема, предложенная Ю.Д. Клеоповым (1990), где основным подходом при выделении геоэлементов используются параметры, описывающие форму ареала видов, его крупных фрагментов, оставив в стороне периферические участки, в условиях которых вид становится более редким и нетипичным. Данная система геоэлементов была успешно апробирована Ю.Д. Клеоповым на примере флоры широколиственных лесов Европейской части СССР. Эта система достаточно гибкая и удобная для применения.

Всего в составе флоры лесов Центрального Предкавказья нами выявлено 27 подтипов, объединенных в 13 типов геоэлементов (рис. 5). 


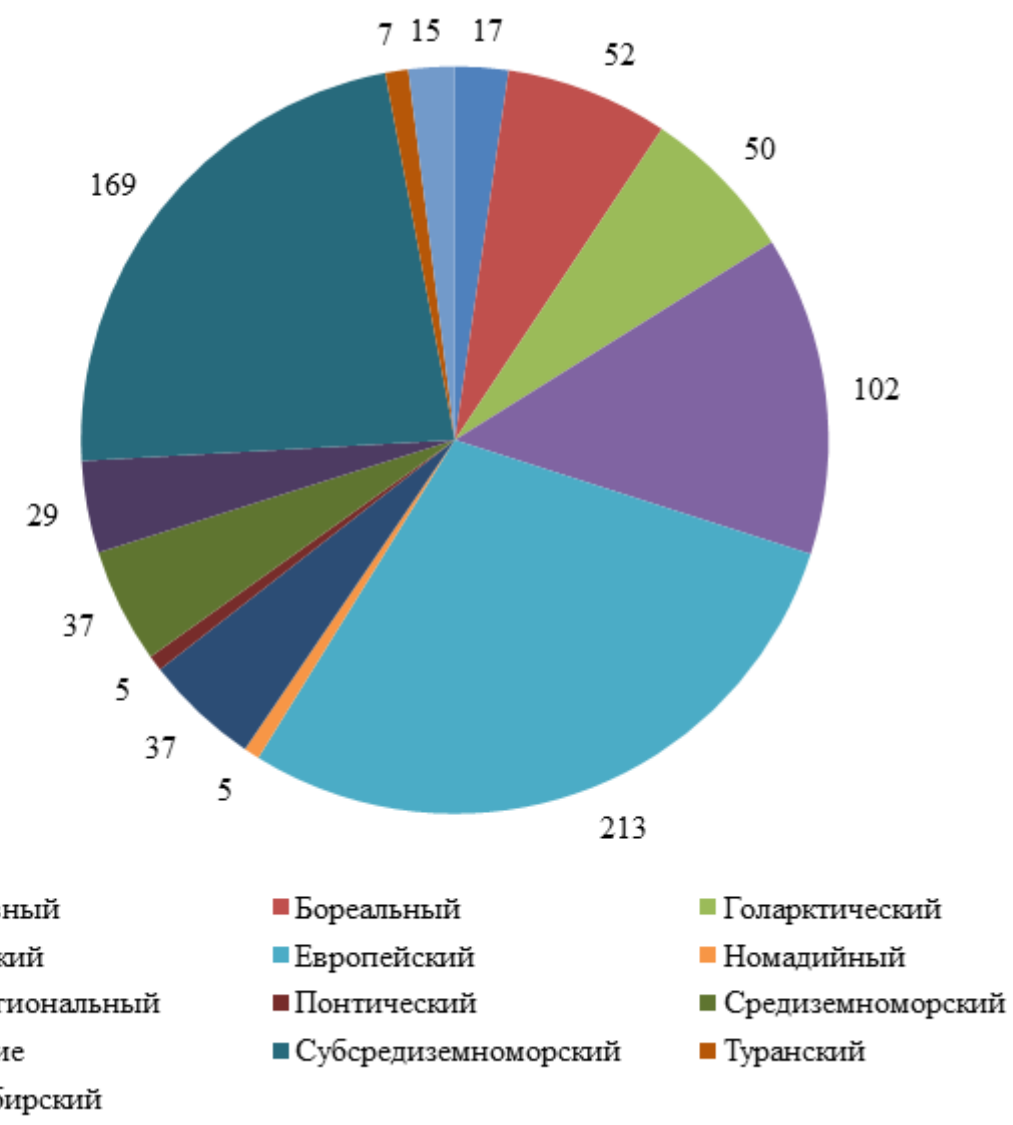

Рисунок 5. Соотношение геоэлементов флоры лесов Центрального Предкавказья

Европейский тип явно доминирует и составляет основу всей флоры лесов. Среди относящихся сюда элементов на первом месте находится собственно европейский, на втором - западноевропейский и европейский дизъюнктивный и лишь на четвертом центральноевропейский. При этом центральноевропейские и западноевропейские элементы являются непостоянной примесью в составе лесных сообществ.

Вслед за европейским типом идет субсредиземноморский, евразийский и бореальный элементы. Поскольку представители субсредиземноморских и бореальных видов преимущественно светолюбивы, а основное господствующее ядро современной флоры лесов Центрального Предкавказья - европейские и евразийские типы - более или менее тенелюбивые, можно полагать, что общий ход развития флоры этих лесов шел в направлении инкубации европейского комплекса на субсредиземноморские и бореальные типы с постепенным их вытеснения. Что касается степного номадийного типа, то его доля в абсолютном спектре незначительна (1.5\%). Эти виды встречаются, преимущественно, в экотонных сообществах, на лесных полянах и светлых лесах, местах вырубок.

Большую роль в географическом спектре изучаемой флоры играют виды с широким ареалом: евразийские (палеарктические), голарктические и плюрирегиональные. К ним относятся луговые, околоводные и полусорные виды. Самой многочисленной из вышеперечисленных групп является группа видов евразийского типа, составляющих основу флоры умеренных широт Евразии. 
В целом, леса Центрального Предкавказья имеют европейскосубсредиземноморско-евразийский с бореальной и кавказской примесью спектр географических элементов.

\section{ЗАКЛЮЧЕНИЕ}

Несмотря на то, что территория Центрального Предкавказья отличается крайне низким показателем лесистости и площади лесных массивов, благодаря наличию сложного рельефа и сочетанию природно-климатических факторов, здесь сформировались условия формирования богатой флоры. Изучение этих лесов имеет особую научную ценность, поскольку они представляют собой остатки единого лесного массива, который занимал большую часть территории региона и сохранял связи с лесами Восточноевропейской равнины, что подтверждается высоким уровнем флористического сходства и близкой таксономической структурой флор лесов этих регионов.

\section{БЛАГОДАРНОСТИ}

Исследование выполнено в рамках темы государственного задания ЦЭПЛ РАН № 0110-2018-0007, материал обработан за счет средств гранта Российского научного фонда (16-17-10284).

\section{СПИСОК ЛИТЕРАТУРЫ}

Бурда Р.И. Антропогенная трансформация флоры. Киев, 1991. 1987 с.

Вальтер Г. Растительность земного шара. Эколого-физиологическая характеристика: в 3-х томах. М.: Прогресс, 1968-1975. 216 с.

Вульф Е.В. Введение в историческую географию растений, 2-е изд. М.-Л.: Сельхозгиз, $1933.415 \mathrm{c}$.

Гагнидзе Р.И. Географический анализ флороценотического комплекса субальпийского высокотравья Кавказа // Ареалы растений СССР. 1976. Вып. 3. 276 с.

Галушко А.И. Ботанико-географические районы Передовых (Терского и Сунженского) хребтов Чечено-Ингушетии // Флора Северного Кавказа и вопросы её истории. 1976. Вып. 1. C. $170-178$.

Гричук В.П. Географические ландшафты Русской равнины ледникового периода // Природа. 1952. № 2. С. 115-120.

Гроссгейм А.А. Анализ флоры Кавказа // Труды Ботанического института Азерб. ФАН СССР. 1936. Вып. 1. 260 с. 
Гроссгейм А.А. Растительный покров Кавказа. М.: изд-во МОИП, 1948. 267 с.

Зернов А.С., Онипченко В.Г. Сосудистые растения Карачаево-Черкесской Республики. Москва: изд-во Макс Пресс, 2011. 238 с.

Иванов А.Л. Флора Предкавказья и её генезис. Ставрополь: изд-во СГУ, 1998. 204 с.

Клеопов Ю.Д. Анализ флоры широколиственных лесов европейской части СССР. Киев: Наукова думка, 1990. 350 с.

Красная книга Российской Федерации (растения и грибы). Москва, 2008. 855 с.

Красная книга Ставропольского края. Растения. Ставрополь, 2002. 361 с.

Матишов Г.Г., Калмыков, Н.П. Представление об истории современных ландшафтов Ергенинской возвышенности и Ставропольского выступа // Вестник Южного научного центра. 2013. Т. 9. № 2. С. 32-37.

Морозова O.B. Таксономическое богатство флоры Восточной Европы: факторы пространственной дифференциации. Москва: Наука, 2008. 323 с.

Новосад В.В. Флора керченско-таманского региона. Киев, 1992. 278 с.

Портениер Н.Н. Методические вопросы выделения географических элементов флоры Кавказа // Бот. журнал. 2000. Т. 85. № 9. 26-33 с.

Серебряков И.Г. Эко ло гическая мо рфо ло гия растений. Жизненные фо рмы покрытосеменных и хвойных. М.: Высшая школа, 1962. 379 с.

Сагателян А.А. Классификация географических элементов флоры Армении // Ботанический журнал. 1997. Т. 82. № 9. С. 25-38.

Толмачёв А.И. Введение в географию растений. Л.: изд-во Ленинградского ун-та. 1974. $224 \mathrm{c}$.

Толмачёв А.И. Методы сравнительной флористики и проблемы флорогенеза. Новосибирск: Наука, 1986. 195 с.

Фёдорова Р.В. Лесные фазы в растительном покрове Ергеней и Ставрополья в позднем голоцене (по данным спорово-пыльцевого анализа) // Труды Института географии и палеогеографии СССР. Москва, 1955. Вып. 63. 13. С. 57-127.

Харадзе А.Л. К ботанико-географическому районированию высокогорий Большого Кавказа // Проблемы ботаники. 1966. Т. VIII. С. 1-28.

Черепанов С.К. Сосудистые растения России и сопредельных государств. СПб.: Мир и семья-95,1995. 990с.

Шевченко H.Е., Белоус В.Н. Биоморфологический анализ флоры пойменных лесов среднего течения реки Кумы (Ставропольский край) // Проблемы ботаники Южной Сибири и Монголии. Материалы 7 международной научно-практической конференции. Барнаул, 2008. C. 17-18. 
Шевченко H.Е., Белоус В.Н. Анализ географических элементов флоры пойменных лесов среднего течения реки Кумы (Ставропольский край) // Проблемы ботаники Южной Сибири и Монголии. Материалы 8 международной научно-практической конференции. Барнаул, 2009. С. 144-147.

Шевченко Н.Е. Новые местонахождения редких и исчезающих видов растений во флоре Ставропольского края // Проблемы экологической безопасности и сохранение природно-ресурсного потенциала. Сборник материалов 7 Международной научнопрактической конференции. Ставрополь, 2011. С. 225-227.

Шевченко H.E. Леса Центрального Предкавказья: флористический состав, растительность и проблемы охраны Дисс. ... канд. биол. наук (спец. 03.02.01). Москва: МПГУ, 2013. 247 с.

Шевченко Н.Е., Викторов В.П. Леса Центрального Предкавказья // Вестник Тамбовского университета. Серия: Естественные и технические науки. 2014. Т. 19. № 5. С. $1622-1625$.

Шевченко H.E., Белоус В.Н. Конспект флоры лесо в Центрального Прдкавказья. Москва-Ставрополь: Параграф, 2014. 136 с.

Юриев Б.А. Очерк системы основных понятий флористики // Теоретические и методические проблемы сравнительной флористики. 1987. Вып. 2. С. 242-266.

Raunkiaer Ch. Recherches statistiques sur les formations vegetales. Biologiske Meddelelser // Kongelige Danske Videnskabernes Selskab. 1905. Vol. 1. No 3. pp. 1-80.

\section{REFERENCES}

Burda R.I., Antropogennaya transformaciya flory (Anthropogenic transformation of flora), Kiev, 1991, 1987 p.

Cherepanov S.K., Sosudistye rasteniya Rossii i sopredel'nyh gosudarstv (Vascular plants of Russia and neighboring countries). Saint-Petersburg: Mir i sem'ya-95, 1995, 990 p.

Fyodorova R.V, Lesnye fazy v rastitel'nom pokrove Ergenej $i$ Stavropol'ya v pozdnem golocene (po dannym sporovo-pyl'cevogo analiza) (Forest phases in the vegetation cover of the Ergenei and Stavropol regions in the late Holocene (according to the data of the spore-pollen analysis)), Trudy Instituta geografii i paleogeografii SSSR, 1955, Issue. 63, pp. 57-127.

Gagnidze R.I., Geograficheskij analiz florocenoticheskogo kompleksa subal'pijskogo vysokotrav'ya Kavkaza (Geographical analysis of the florocenotic complex of the subalpine tall grass of the Caucasus), Arealy rastenij SSSR, 1976, Vol. 3, 276 p.

Galushko A.I., Botaniko-geograficheskie rajony Peredovyh (Terskogo $i$ Sunzhenskogo) hrebtov Checheno-Ingushetii (Botanico-geographical areas of the Forward (Tere and Sunzhensky) 
ridges of Checheno-Ingushetia), Flora Severnogo Kavkaza i voprosy eyo istorii, 1976, Issue 1, pp. 170-178.

Grichuk V.P., Geograficheskie landshafty Russkoj ravniny lednikovogo perioda (Geographical landscapes of the Russian plain of the glacial period), Priroda, 1952, No 2, pp. 115-120.

Grossgejm A.A., Analiz flory Kavkaza (Analysis of the flora of the Caucasus), Trudy Botanicheskogo instituta Azerb. FAN SSSR, 1936, Issue 1, 260 p.

Grossgejm A.A., Rastitel'nyj pokrov Kavkaza (Vegetative cover of the Caucasus.), Moscow: izd-vo MOIP, 1948, 267 p.

Haradze A.L., K botaniko-geograficheskomu rajonirovaniyu vysokogorij Bol'shogo Kavkaza (To the botanical-geographical zoning of the high mountains of the Greater Caucasus), Problemy botaniki, 1966, Vol. VIII, pp. 1-28.

Ivanov A.L., Flora Predkavkaz'ya $i$ eyo genesis (Flora of Ciscaucasia and its genesis), $\quad$ Stavropol: $\quad$ izd-vo $\quad$ SGU, $\quad 1998, \quad 204 \quad$ p.

Kleopov Yu.D., Analiz flory shirokolistvennyh lesov evropejskoj chasti SSSR (Analysis of the flora of deciduous forests of the European part of the USSR), Kiev: Naukova dumka, 1990, 350 p.

Krasnaya kniga Rossijskoj Federacii (rasteniya i griby) (Red Data Book of the Russian Federation (plants and mushrooms), Moscow, 2008, 855 p.

Krasnaya kniga Stavropol'skogo kraya, Rasteniya (Red Book of the Stavropol Territory. Plants), Stavropol, 2002, $361 \mathrm{p}$.

Matishov G.G., Kalmykov, N.P., Predstavlenie ob istorii sovremennyh landshaftov Ergeninskoj vozvyshennosti $i$ Stavropol'skogo vystupa (The idea of the history of modern landscapes of the Ergeninskaya Upland and the Stavropol Ridge), Vestnik Yuzhnogo nauchnogo centra, 2013, Vol. 9, No 2, pp. 32-37.

Morozova O.V., Taksonomicheskoe bogatstvo flory Vostochnoj Evropy: faktory prostranstvennoj differenciacii (Taxonomic wealth of the flora of Eastern Europe: factors of spatial differentiation), Moskva: Nauka, 2008, 323 p.

Novosad V.V., Flora kerchensko-tamanskogo regiona (Flora of the Kerch-Taman region), Kiev, 1992, $278 \mathrm{p}$.

Portenier N.N., Metodicheskie voprosy vydeleniya geograficheskih ehlementov flory Kavkaza (Methodological issues of highlighting the geographical elements of the flora of the Caucasus), Bot. zhurnal, 2000, Vol .85, No 9, pp. 26-33.

Raunkiaer Ch., Recherches statistiques sur les formations vegetales. Biologiske Meddelelser, Kongelige Danske Videnskabernes Selskab, 1905, Vol. 1, No 3, pp.1-80. 
Serebryakov I.G., Ehkologicheskaya morfologiya rastenij. Zhiznennye formy pokrytosemennyh $i$ hvojnyh (Ecological morphology of plants. Life forms of angiosperms and conifers), Moscow: Vysshaya shkola, 1962, 379 p.

Sagatelyan A.A., Klassifikaciya geograficheskih ehlementov flory Armenii (Classification of geographical elements of the flora of Armenia), Botanicheskij zhurnal, 1997, Vol. 82, No 9, pp. 25-38.

Shevchenko N.E., Belous V.N., Biomorfologicheskij analiz flory pojmennyh lesov srednego techeniya reki Kumy (Stavropol'skij kraj) (Biomorphological analysis of flora of floodplain forests of the middle reaches of the Kuma River (Stavropol Territory)), Problemy botaniki Yuzhnoj Sibiri $i$ Mongolii. Materialy 7 mezhdunarodnoj nauchno-prakticheskoj konferencii, Barnaul, 2008, pp. 17-18.

Shevchenko N.E., Belous V.N., Analiz geograficheskih ehlementov flory pojmennyh lesov srednego techeniya reki Kumy (Stavropol'skij kraj) (Analysis of the geographical elements of the flora of the floodplain forests of the middle reaches of the Kuma River (Stavropol Territory)), Problemy botaniki Yuzhnoj Sibiri i Mongolii. Materialy 8 mezhdunarodnoj nauchno-prakticheskoj konferencii, Barnaul, 2009, pp. 144-147.

Shevchenko N.E., Novye mestonahozhdeniya redkih i ischezayushchih vidov rastenij vo flore Stavropol'skogo kraya (New Locations of Rare and Endangered Plant Species in the Flora of the Stavropol Territory), Problemy ehkologicheskoj bezopasnosti i sohranenie prirodno-resursnogo potenciala. Sbornik materialov 7 Mezhdunarodnoj nauchno-prakticheskoj konferencii, Stavropol, 2011, pp. 225-227.

Shevchenko N.E., Lesa Central'nogo Predkavkaz'ya: floristicheskij sostav, rastitel'nost' $i$ problemy ohrany (Forests of Central Ciscaucasia: floristic composition, vegetation and protection problems), Moscow: MPGU, 2013, 247 p.

Shevchenko N.E., Viktorov V.P., Lesa Central'nogo Predkavkaz'ya (Forests of Central Ciscaucasia), Vestnik Tambovskogo universiteta. Seriya: Estestvennye i tekhnicheskie nauki, 2014, Vol. 19, No 5, pp. 1622-1625.

Shevchenko N.E., Belous V.N., Konspekt flory lesov Central'nogo Predkavkaz'ya (A summary of the forest flora of the Central Prdkavkaz), Moscow-Stavropol: Paragraf, 2014, 136 p.

Val'ter G., Rastitel'nost' zemnogo shara. EHkologo-fiziologicheskaya harakteristika: $v$ 3-h tomah (Ecological and physiological characteristics: in 3 volumes), Moscow: Progress, 1968-1975. $216 \mathrm{p}$.

Tolmachyov A.I., Vvedenie $v$ geografiyu rastenij (Introduction to plant geography), Leningrad: izd-vo Leningradskogo un-ta, 1974, 224 p.

Tolmachyov A.I., Metody sravnitel'noj floristiki i problemy florogeneza (Methods of comparative floristics and problems of florogenesis), Novosibirsk: Nauka, 1986, 195 p. 
Vul'f E.V., Vvedenie $v$ istoricheskuyu geografiyu rastenij, 2-e izd. (Introduction to the historical geography of plants, 2-nd ed.), Moscow-Leningrad: Sel'hozgiz, 1933, 415 p.

Yurcev B.A., Ocherk sistemy osnovnyh ponyatij floristiki (Essay on the system of basic concepts of floristics), Teoreticheskie i metodicheskie problemy sravnitel'noj floristiki, 1987, Issue 2, pp. 242-266.

Zernov A.S., Onipchenko V.G., Sosudistye rasteniya Karachaevo-Cherkesskoj Respubliki (Vascular plants of the Karachay-Cherkess Republic), Moscow: izd-vo Maks Press, 2011, $238 \mathrm{p}$.

\title{
REVIEW OF THE FLORA OF FORESTS OF THE CENTRAL CISCAUCASUS
}

\author{
N.E. Shevchenko \\ ${ }^{1}$ Center for Forest Ecology and Productivity of the RAS \\ Profsoyuznaya st. 84/32 bldg. 14, Moscow, 117997, Russia \\ E-mail: neshevchenko@gmail.com \\ Received 22 August 2018
}

The taxonomic, ecologo-cenotic and geographical diversity of the flora of forests of the Central Ciscaucasia, counting 735 species of vascular plants belonging to 101 families and 353 genera is considered in the article. The taxonomic structure of the forest flora according to the composition of the first ten families corresponds to the flora of the Ciscaucasia. Forests have a European-sub-Mediterranean-Eurasian with a boreal and Caucasian impurity range of geographic elements. The general course of development of the forest flora of the region as well as the forests of the Eastern European Plain went in the direction of incubation of the European complex into subMediterranean and boreal types with their gradual displacement.

Key words: Central Ciscaucasia, forests, flora, taxonomic structure, eco-cenotetic group, bimorph, geoelement

Рецензент: д.б.н. профессор Шустов М.В. 